\title{
Perancangan Kafe Terapung di Desa Lendang Are
}

\author{
Erdinsyah Mahendra ${ }^{1}$, Riri Chairiyah ${ }^{2}$ \\ ${ }_{1}^{1}$ Program Studi Arsitektur, Fakultas Sains \& Teknologi, Universitas 'Aisyiyah Yohyakarta \\ 2 Program Studi Arsitektur, Fakultas Sains \& Teknologi, Universitas 'Aisyiyah Yohyakarta \\ Email: erdinsyah007@gmail.com
}

\begin{abstract}
ABSTRAK
Bangunan terapung menjadi hobi yang cukup banyak diminati untuk mampu mengeksplor lebih jauh potensi tapak yang berupa perairan, terutama sebagai destinasi wisata. Bendungan Lendang Are memiliki cukup banyak potensi untuk menjadi destinasi wisata air dan mampu menunjang perekonomian warga di sekitarnya. Salah satu fasilitas yang harus ada pada sebuah destinasi wisata air adalah rumah makan, restoran, warung, kafe atau sejenisnya yang melayani kebutuhan konsumsi pengunjung. Dalam prosesnya, perancangan dan eksplorasi desain, terdapat beberapa tahapan seperti perumusan gagasan, pengumpulan informasi, analisis dan sintesis, perancangan, dan evaluasi yang menghasilkan sebuah hasil rancangan berupa kafe terapung. Perancangan kafe terapung harus memperhatikan kelestarian lingkungan dengan menghindari reklamasi, maka kehidupan satwa air di bendungan dan sekitarnya tidak terganggu. Bentuk dan ruang pada bangunan didesain dengan mempertimbangkan keseimbangan beban terhadap plat atau struktur apung. Struktur apung harus memenuhi standar untuk menahan beban bangunan dan penggunanya. Sistem tambat digunakan untuk menjaga posisi bangunan dan menyesuaikan bangunan dengan ketinggian air yang suatu waktu dapat berubah.
\end{abstract}

Kata Kunci: Kafe, Apung, Bendungan.

Article history: Received 2021-01-26; Revised 2021-03-26; Accepted 2021-05-26;

\section{PENDAHULUAN}

Embung Tandung Andung di Desa Lendang Are, Kabupaten Lombok Tengah berfungsi sebagai bendungan irigasi yang mengontrol pasokan air untuk persawahan di desa tersebut. Bendungan adalah bangunan yang berupa urugan tanah, urugan batu, beton, dan atau pasangan batu yang dibangun selain untuk menahan dan menampung air, dapat pula dibangun untuk menahan dan menampung limbah tambang (tailing), atau menampung lumpur sehingga terbentuk waduk (Peraturan Pemerintah No. 37 Tahun 2010 tentang Bendungan). Bendungan atau dalam bahasa lokalnya disebut embung di Desa Lendang Are ini memiliki pemandangan yang sangat bagus dengan persawahan di sebelah kiri dan kanan yang memiliki elevasi lebih tinggi, sehingga menciptakan kesan seperti lembah. Peran Embung Tandung Andung sebagai irigasi untuk persawahan di Desa Lendang Are dan sekitarnya cukup vital. Menurut Kartasapoetra (1994), irigasi merupakan kegiatan penyediaan dan pengaturan air untuk memenuhi kepentingan pertanian dengan memanfaatkan air yang berasal dari air permukaan dan tanah.

Seiring berjalannya waktu, Embung Tandung Andung mulai dikelola sebagai destinasi wisata sederhana yang digunakan oleh warga sekitar pada sore hari. Setelah mendapatkan suntikan dana desa dari pemerintah pusat, pemerintah Desa Lendang Are memutuskan untuk mengembangkan Embung Tandung Andung sebagai destinasi wisata air yang lebih besar sehingga diharapkan mampu menarik wisatawan dengan segmen yang lebih luas. Menurut Wahid (2015), pariwisata adalah perjajanan dari satu tempat 
ke tempat lain, bersifat sementara, dilakukan perorangan maupun kelompok, sebagai usaha mencari keseimbangan atau keserasian dan kebahagiaan dengan lingkungan hidup dalam dimensi sosial, budaya, alam, dan ilmu. Destinasi wisata adalah suatu kawasan spesifik yang dipilih oleh seseorang pengunjung, yang mana ia dapat tinggal dan berdomisili selama periode waktu tertentu (Hadinoto, 1996). Destinasi wisata air biasanya berupa rangkaian unit-unit atraksi wisata yang disatupadukan dalam sebuah kawasan objek wisata yang berlokasi di perairan atau di sekitar perairan seperti danau, waduk, bendungan, sungai, laut, dan sebagainya. Destinasi wisata air seperti di objek wisata air Denda Seruni, terdapat beberapa unit bangunan terapung seperti menara Eifel yang terbuat dari bambu, gazebo, warung-warung dan kafe. Dari sudut pandang ekonomi, jika berhasil dikembangkan dengan baik menjadi destinasi wisata air yang lebih kompleks, Embung Tandung Andung akan mampu menarik wisatawan yang lebih banyak dengan segmen yang lebih luas untuk datang. Sehingga dengan perancangan kafe dengan sistem bangunan terapung di Embung Tandung Andung diharapkan dapat membantu meningkatkan perekonomian warga di Desa Lendang Are. Tujuan dari penulisan ini adalah menghasilkan desain bangunan kafe terapung yang ramah lingkungan tanpa reklamasi di destinasi wisata air Embung Tandung Andung.

\section{TINJAUAN PUSTAKA}

A. Kafe

Menurut KBBI Daring (2016), kafe adalah tempat makan berkonsep sederhana, biasanya yang disajikan berupa minuman dan makanan ringan. Menurut Kusasi (2010), elemen penting dari sebuah kafe sejak awal adalah fungsi sosialnya, yakni: menyediakan tempat agar orang dapat bertemu, ngobrol, menulis, membaca, baik sendiri maupun bersama teman-teman.

Tabel.1. Analisis Program Ruang Beam Cafe

\begin{tabular}{cccc} 
No. & \multicolumn{2}{c}{ Program Ruang } & \\
\cline { 2 - 4 } & Dama Ruangan & Luas & Jumlah \\
\hline 1 & Ruang Makan & $18 \mathrm{~m}^{2}$ & 1 buah \\
\hline 2 & Kasir/Mini Bar & $\begin{array}{c}72 \mathrm{~m}^{2} \mathrm{dan} \\
\mathrm{m}^{2}\end{array}$ & 2 area \\
\hline 3 & Toilet & $18 \mathrm{~m}^{2}$ & 1 buah \\
\hline 4 & & $25 \mathrm{~m}^{2}$ & 1 area \\
\hline
\end{tabular}

Sumber: hasil analisis, 2020 


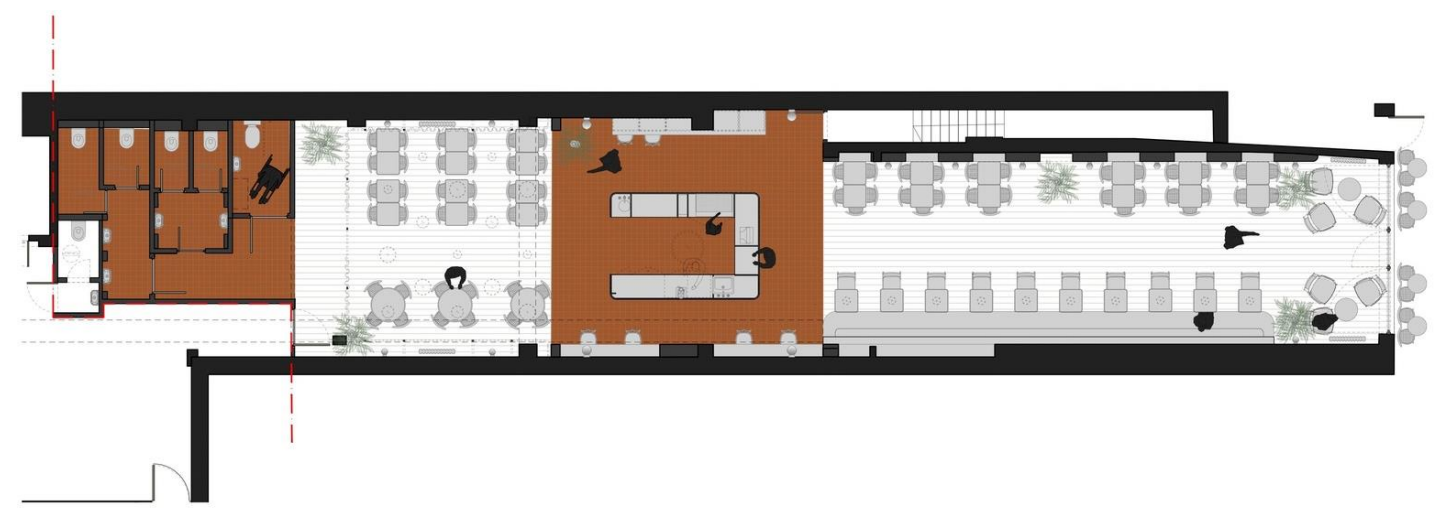

Gambar1. Denah Beam Café

Sumber: Archdaily.com, 2020

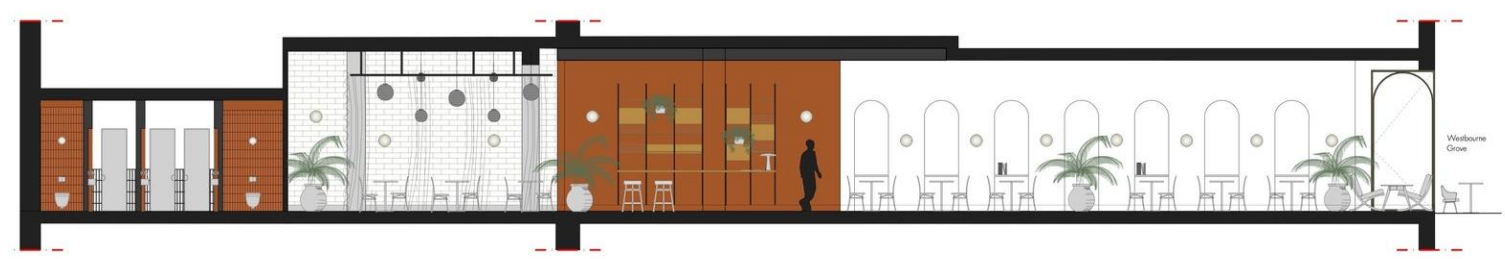

Gambar.2 Potongan Beam Café

Sumber: Archdaily.com, 2020

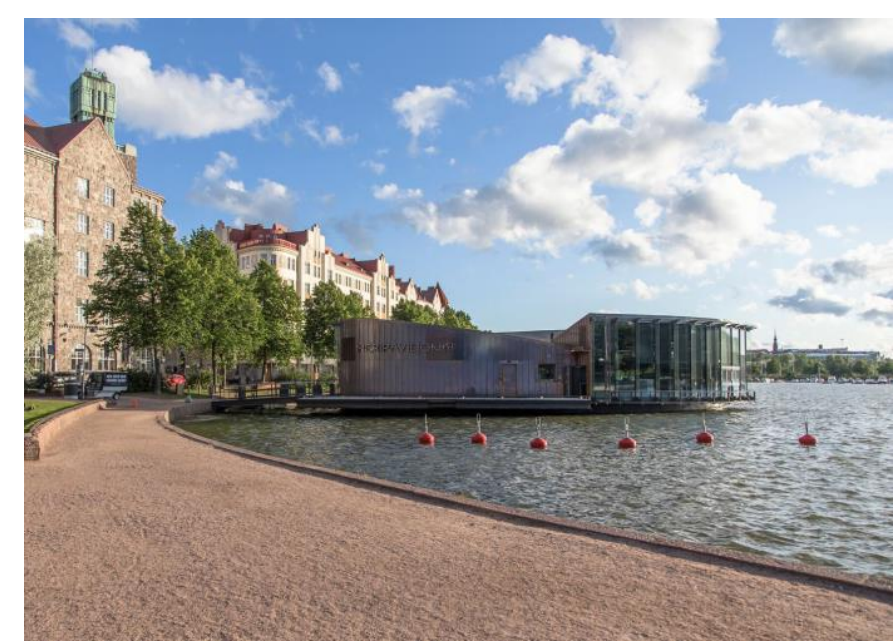

Gambar.3. Meripaviljonki Café di Finlandia

Sumber: Archdaily.com, 2015

B. Bangunan Terapung

Terapung berasal dari kata "apung", menurut KBBI Daring (2016), apung adalah sesuatu yang terapung-apung di permukaan air atau yang dapat ditempatkan di air dan tidak tenggelam. Berdasarkan hal tersebut dapat disimpulkan bahwa bangunan terapung adalah bangunan yang ditempatkan di atas permukaan air dan tidak tenggelam. Menurut Muchsin (2014), kafe terapung termasuk pada bangunan terapung dengan skala 
kecil. Pada bangunan terapung dengan skala kecil, massa bangunan harus memenuhi beberapa persyaratan, antara lain:

1. Bentuk bangunan harus simetris agar pembagian beban pada struktur apung merata dan stabil. Bentuk geometri dasar digunakan pada perancangan ini karena bentukanbentukan tersebut dapat memenuhi kriteria di atas.

2. Menggunakan konstruksi ringan, yaitu menggunakan material seperti kayu, cladding, alumunim, dll. Penggunaan material ini bertujuan agar tidak membebani struktur apung itu sendiri.

\section{PROSES RANCANG DAN EKSPLORASI}

Dalam proses perancangan dan eksplorasi desain kafe terapung di Embung Tandung Andung menggunakan metode komparatif dan analitik. Metode komparatif digunakan untuk membandingkan bangunan dengan jenis yang sama yaitu bangunan terapung sebagai rujukan dalam perancangan desain dan metode analitik digunakan untuk mengetahui halhal yang berkaitan dan dibutuhkan dalam perancangan kafe terapung di Embung Tandung Andung. Proses-proses yang dilalui dalam perancangan ini sebagai berikut:

1. Gagasan

Pada tahap awal dilakukan perumusan gagasan, ini adalah proses pencarian ide dengan memperhatikan perkembangan isu terkini, yang dalam hal ini terkait dengan fasilitas publik terapung yaitu kafe, restoran, rumah makan dan sejenisnya yang terapung di atas air. Melalui ide-ide tersebut didapatkan obyek yang lebih unik dan spesifik sehingga tercipta satu gagasan.

2. Pengumpulan data

Pengumpulan informasi yang berkaitan dengan gagasan untuk diolah dan digunakan dalam tahap perancangan berikutnya.

3. Analisis dan sintesis

Informasi yang berhasil dikumpulkan kemudian diolah menjadi sebuah kesimpulan awal berupa alternatif-alternatif konsep yang kemudian menjadi acuan dalam perancangan.

4. Perancangan

Berdasarkan alternatif-alternatif konsep yang dibuat sebelumnya, dilakukan eksplorasi desain yang meliputi:

a. Eksplorasi bentuk/massa

b. Eksplorasi ruang

c. Eksplorasi struktur

5. Evaluasi

Hasil dari eksplorasi desain kemudian dianalisis ulang sebagai bentuk evaluasi untuk menentukan apakah hasil yang dicapai sudah sesuai dengan gagasan yang dibuat pada tahap awal perancangan. 


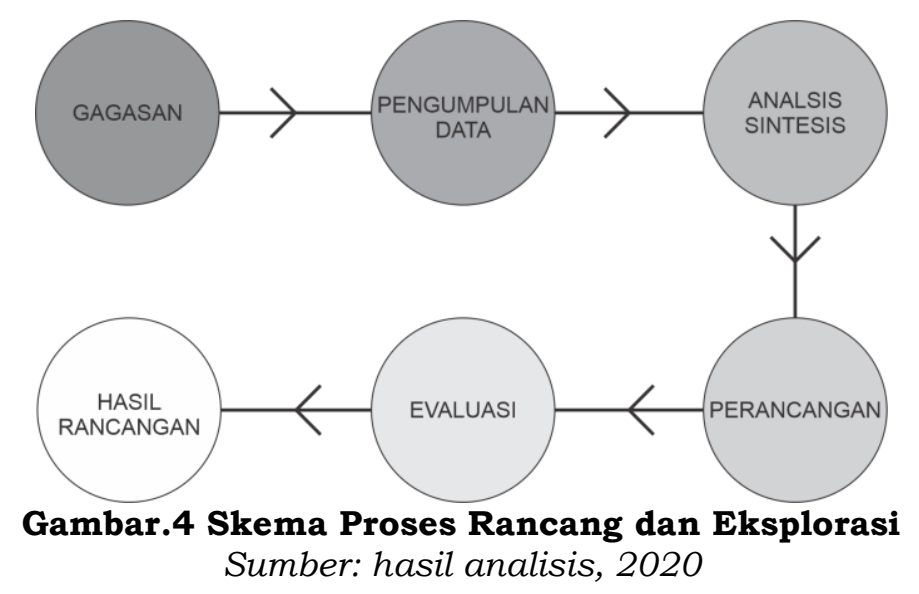

\section{HASIL RANCANGAN}

Embung Tandung Andung direncanakan sebagai destinasi wisata air dengan beragam jenis atraksi yang terletak di darat dan di tengah-tengah perairan bendungan. Sebagai sebuah area yang cukup luas, Embung Tandung Andung memiliki fasilitas yang kompleks mulai dari lokasi parkir, beragam jenis dan lokasi foto, musholla, food court, kolam renang dan beragam atraksi wisata baik di darat maupun di perairan. Embung Tandung Andung memiliki kedalaman sekitar 2 sampai 3 meter dengan permukaan air yang relatif tenang dan arus yang tidak deras. Area bendungan ini memiliki luas sekitar 10.000 meter persegi dan dikelilingi oleh persawahan.

1. Perancangan Massa

Konsep masa yang diaplikasikan adalah terbuka dan menyatu dengan alam. Material yang ditonjolkan adalah kayu, sehingga sesuai dengan kondisi di sekitar. Area untuk pengunjung terbuka sehingga dapat menikmati potensi tapak dengan baik.

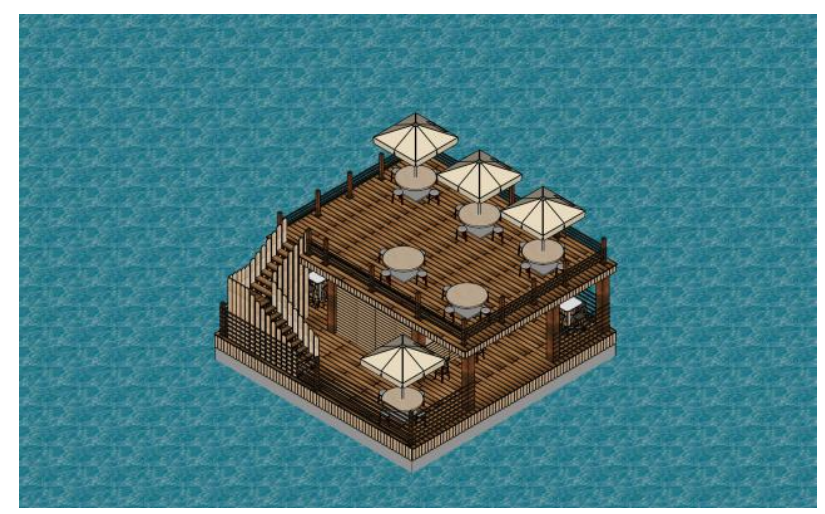

Gambar.5. Bentuk Massa Bangunan

Sumber: hasil rancangan, 2020

Perancangan Kafe Terapung di Desa Lendang Are 
2. Perancangan Ruang

Ruangan pada kafe terapung berdasarkan fungsi dan penggunanya dibagi menjadi dua, yaitu area pegawai (privat) dan area pengunjung (publik). Area pegawai berupa dapur dan mini bar sedangkan area pengunjung berupa ruang terbuka di lantai 1 dan lantai 2 . Pengaplikasian ruang terbuka tersebut untuk memaksimalkan potensi tapak.

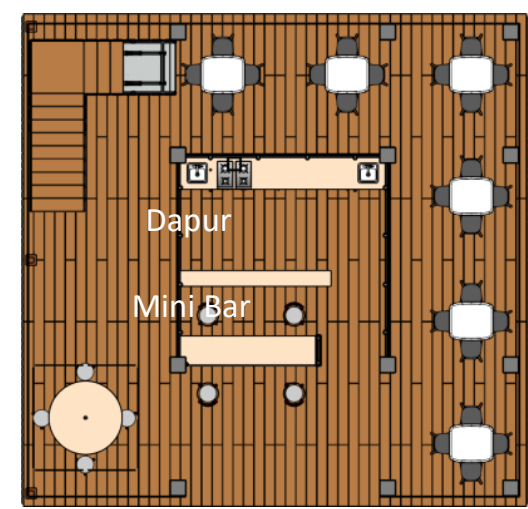

Gambar.6. Denah Lantai 1

Sumber: hasil rancangan, 2020

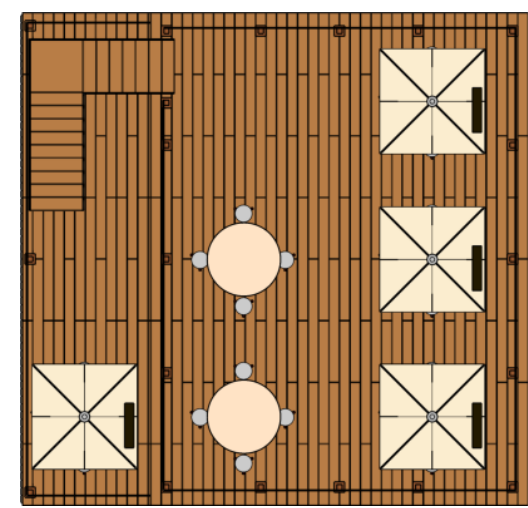

Gambar.7. Situasi

Sumber: hasil rancangan, 2020

3. Perancangan Struktur dan Konstruksi Bangunan

a. Massa Bangunan

Salah satu persyaratan konstruksi bangunan terapung adalah memiliki massa yang simetris untuk menyeimbangkan pembagian beban pada daya apung. Demi memaksimalkan ruang, bentuk bangunan dibuat persegi dan tidak simetris, sehingga pada landasan apung dibuat konfigurasi untuk menyeimbangkan beban. Bentuk persegi juga digunakan untuk mempertegas bentuk dengan kesan yang kokoh. 


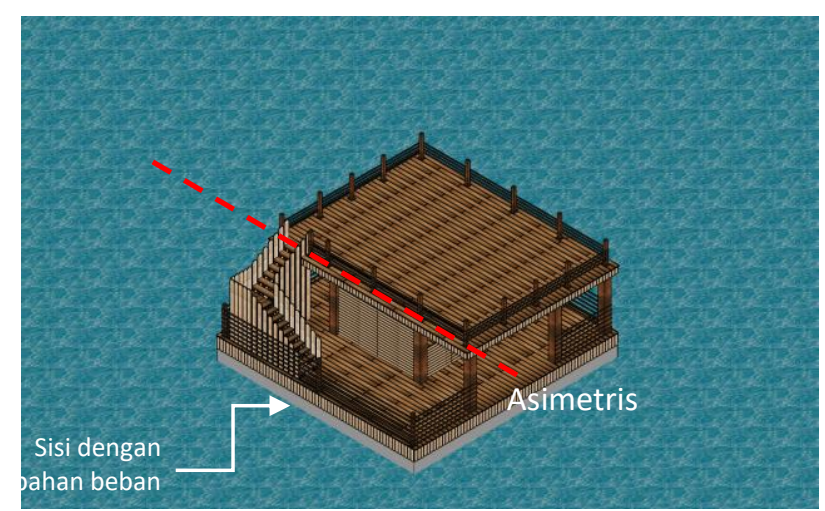

Gambar.8. Massa Bangunan

Sumber: hasil rancangan, 2020

b. Atap/rooftop

Untuk memkasimalkan daya tampungnya, atap disusun dengan rangka yang lebih kokoh sehingga mampu menahan beban yang besar seperti beberapa meja, kursi dan manusia. Atap difungsikan menjadi lantai 2 atau roof top dengan lapisan lantai yang tahan air. Penggunaan material fiber untuk membuat atap atau lantai 2 menjadi kedap air yang kemudian dilapis dengan finishing lantai kayu (papan).

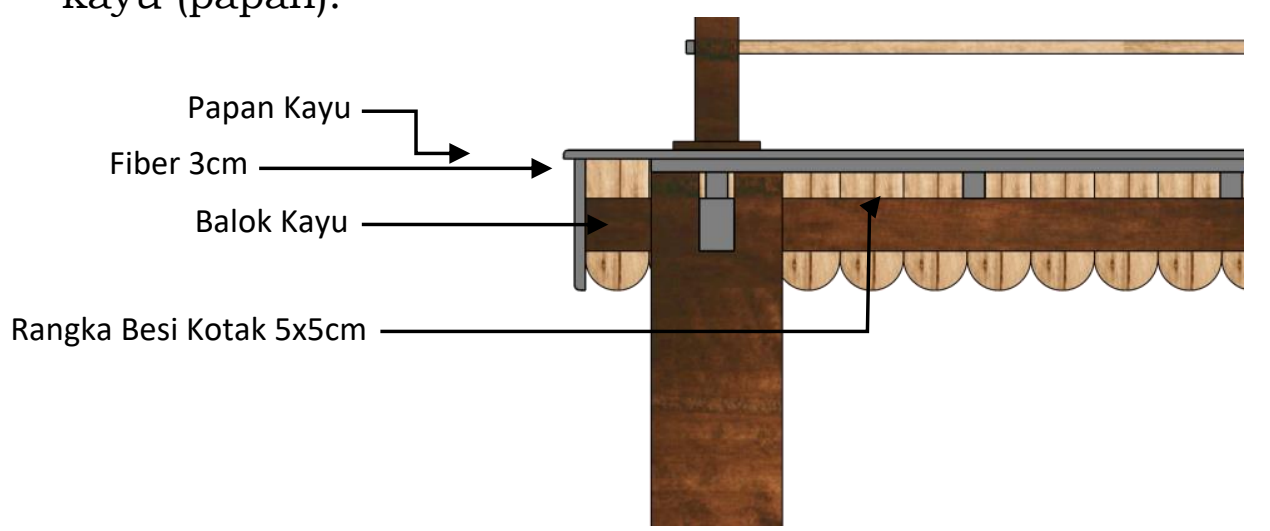

Gambar.9. Susunan Atap/Lantai 2

Sumber: hasil rancangan, 2020

c. Landasan Apung

Landasan apung yang digunakan adalah b-foam ${ }^{\circledR}$ EPS. Expanded Polystrean (EPS) adalah material yang berdaya apung sangat baik, dikarenakan berat jenisnya yang hanya kurang dari 3\% berat jenis air. 


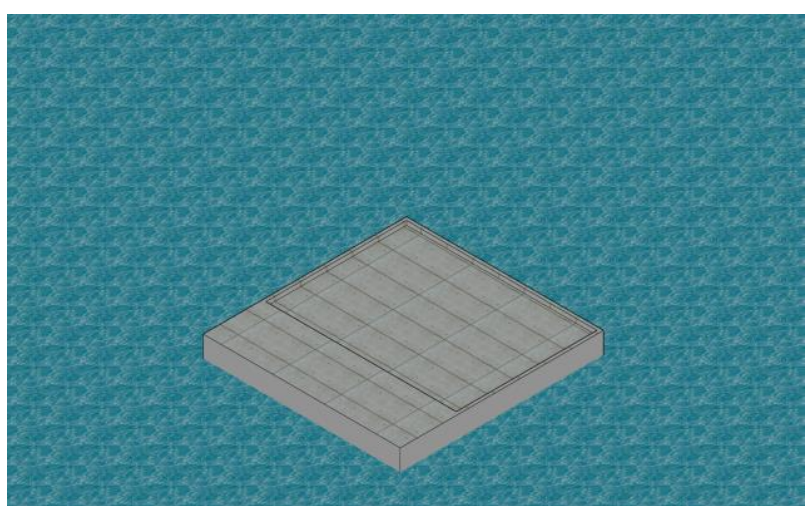

Gambar.10. Landasan Apung

Sumber: hasil rancangan, 2020

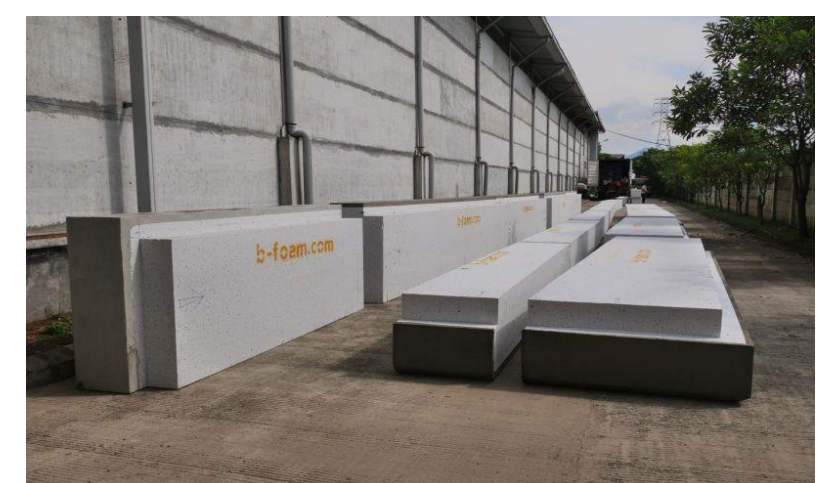

Gambar.11. Modul b-foam ${ }^{\circledR}$ EPS Sebelum Dirakit

Sumber: $\underline{w w w . b-p a n e l . c o m}, 2021$

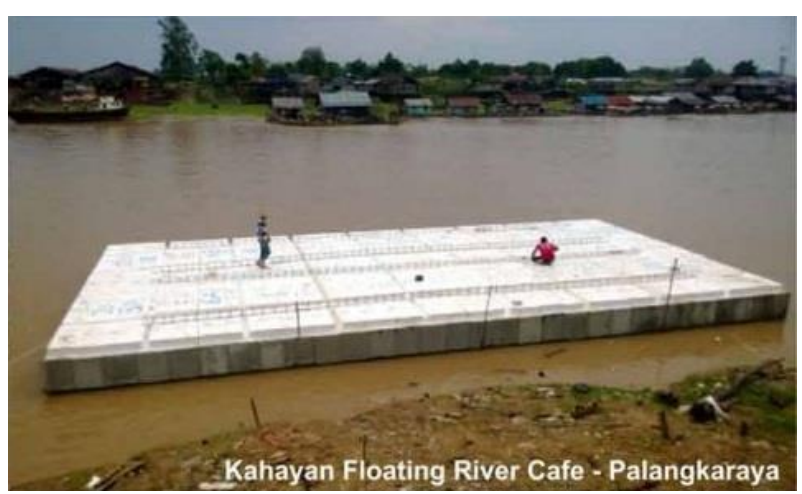

Gambar.12. Landasan Apung b-foam EPS

Sumber: www.b-panel.com, 2021

Modul b-foam ${ }^{\circledR}$ EPS dibuat di pabrik (prefabricated) dengan sudah terpasangnya casing pelindung. Modul-modul tersebut kemudian dirakit, dikuatkan dengan wiremesh baja, lalu di atasnya dituangkan (cor) dengan beton. Semua proses ini dilakukan di atas air. Landasan apung yang telah selesai dengan sangat mudah dapat ditarik kelokasi akhir yang diinginkan. 


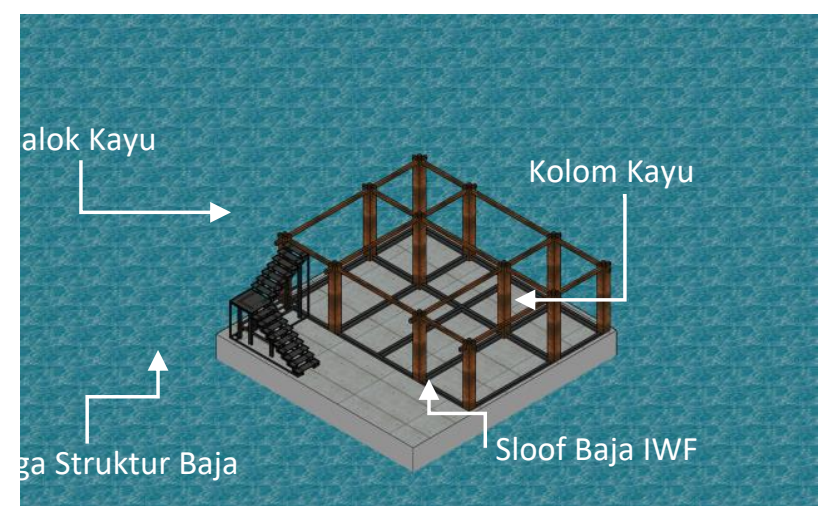

Gambar.13 Landasan Apung dan Rangka Struktur

Sumber: hasil rancangan, 2020

Rangka struktur bangunan dipasang di atas landasan apung dan disatukan dengan baut.

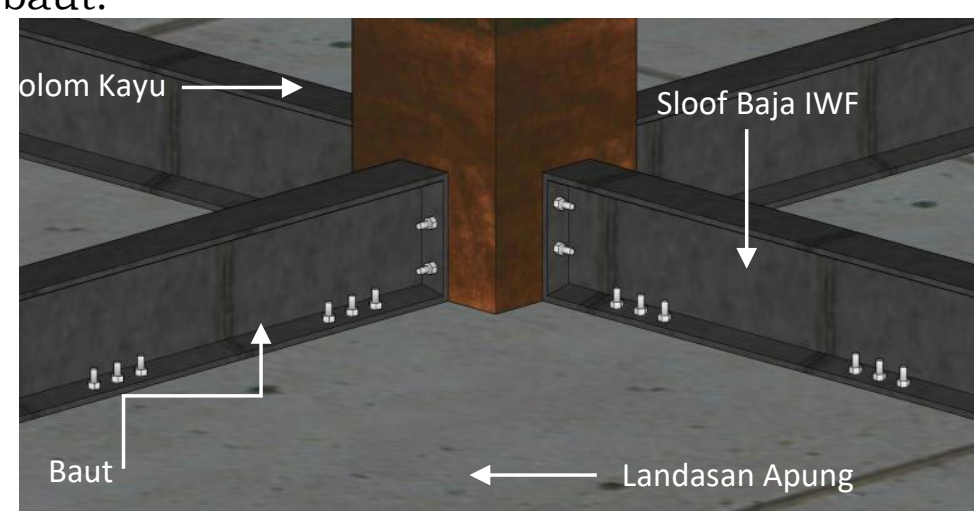

Gambar.14 Ilustrasi Sambungan

Sumber: hasil rancangan, 2020

d. Sistem Tambat

Untuk menjaga bangunan terapung tetap pada posisinya diperlukan sebuah sistem tambat. Sistem tambat yang digunakan adalah sistem tambat dengan tiang pancang. Sistem ini menggunakan prinsip rumah apung tradisional dimana bangunan terapung dikaitkan dengan sebuah stuktur tiang pancang yang terikat kokoh dengan dasar perairan.

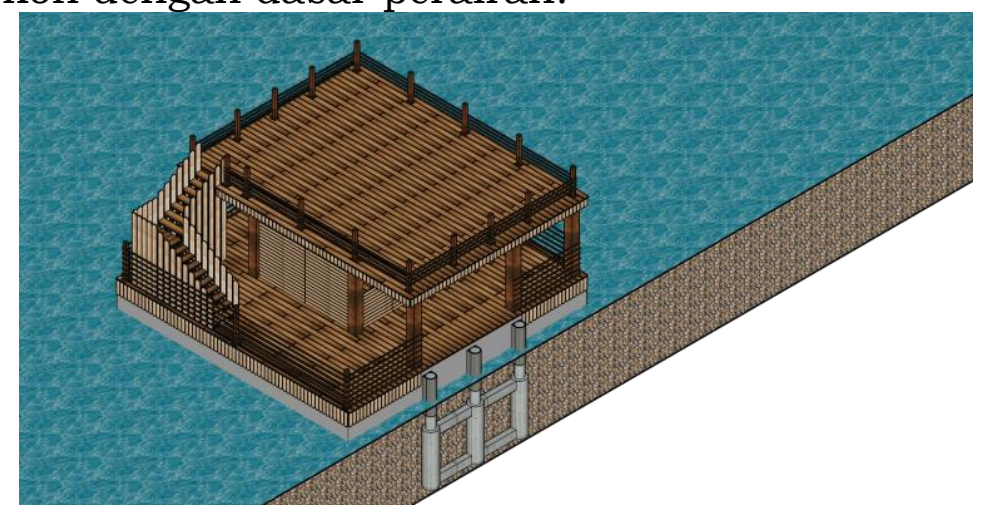

Gambar.15 Sistem Tambat Tiang Pancang Sumber: hasil rancangan, 2020

Perancangan Kafe Terapung di Desa Lendang Are 
Seperti yang terlihat pada gambar.15 terdapat 3 tiang pancang pada satu sisi bangunan terapung untuk menjaga posisi bangunan.

e. Sirkulasi dan Penempatan Massa

Alur sirkulasi untuk mencapai bangunan kafe terapung dibuat menyesuaikan diri dengan desain kawasan Embung tandung Andung secara keseluruhan.

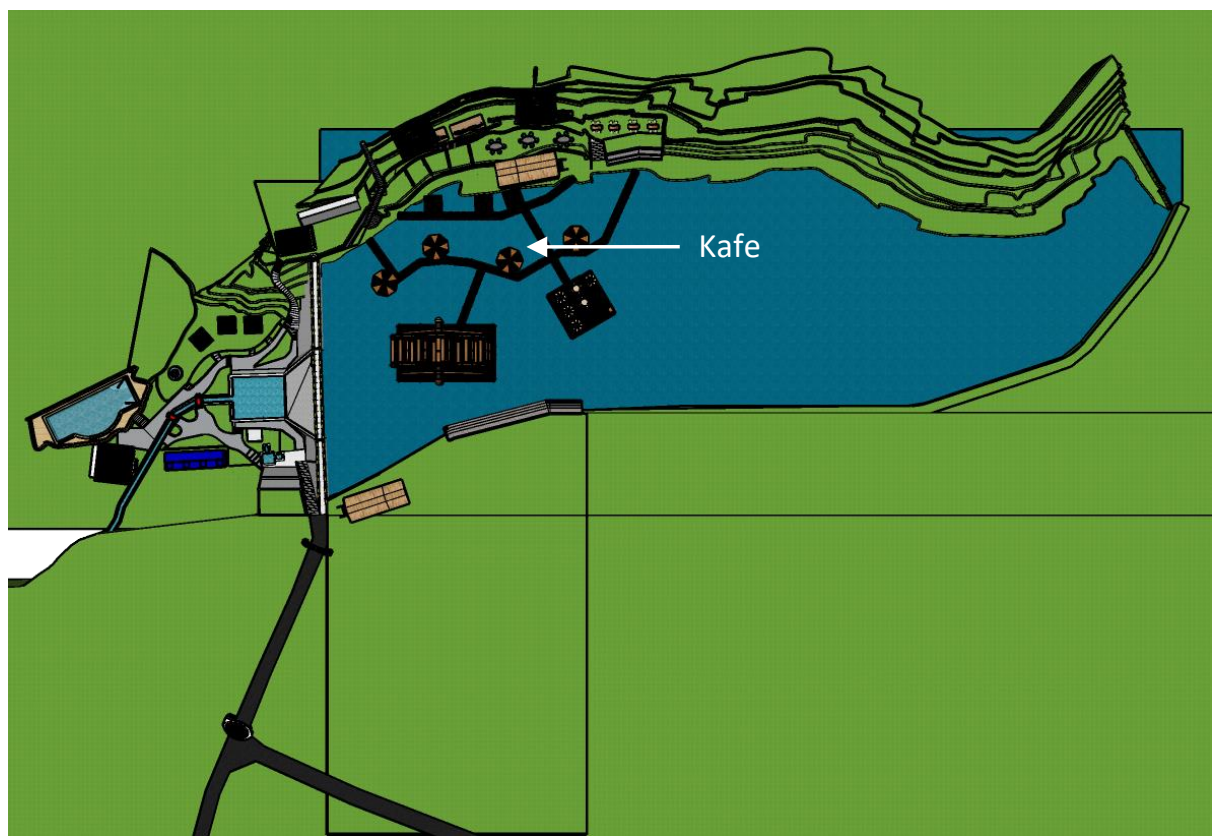

Gambar.16 Rencana Kawasan Embung Tandung Andung

Sumber: dokumen perancangan Embung Lendang Are, 2020

\section{SIMPULAN}

Ilmu pengetahuan dan teknologi di bidang arsitektur terus mengalami perkembangan, bangunan terapung menjadi salah satu inovasi yang unik dan menarik dalam rangka memanfaatkan potensi perairan di Indonesia. Bangunan terapung menjadi hobi yang cukup banyak diminati untuk mampu mengeksplor lebih jauh potensi tapak yang berupa perairan, terutama sebagai destinasi wisata. Bendungan Lendang Are memiliki cukup banyak potensi untuk menjadi destinasi wisata air dan akan mampu menunjang perekonomian warga di sekitarnya. Salah satu fasilitas yang harus ada pada sebuah destinasi wisata air adalah rumah makan, restoran, warung, kafe atau sejenisnya yang melayani kebutuhan konsumsi pengunjung.

Dalam perancangan kafe terapung, harus memperhatikan dampak terhadap lingkungan, dengan menghindari reklamasi maka kehidupan 
satwa air di bendungan dan sekitarnya tidak terganggu. Bentuk dan ruang pada bangunan didesain dengan mempertimbangkan keseimbangan beban terhadap plat atau struktur apung. Struktur apung harus memenuhi standar untuk menahan beban bangunan dan penggunanya. Sistem tambat digunakan untuk menjaga posisi bangunan dan menyesuaikan bangunan dengan ketinggian air yang suatu waktu dapat berubah.

\section{DAFTAR RUJUKAN}

Muchsin, 2014. Penginapan Terapung Waduk Batujai Sebagai Fasilitas Penunjang Kegiatan Wisata Di Pulau Lombok. Jurnal Mahasiswa Arsitektur Universitas Brawijaya, (online) Vol. 2, No. 2, (http://arsitektur.studentjournal.ub.ac.id/index.php/jma/article/view L46) diakses 16 Januari 2021.

Kamus Besar Bahasa Indonesia Daring. 2016.

Peraturan Pemerintah No.37 Tahun 2010 tentang Bendungan. 